Journal of the Egyptian Society of Parasitology, Vol.43, No.3, December 2013 J. Egypt. Soc. Parasitol., 43(3), 2013: 723 - 735

\title{
NATURAL INFECTION OF BABOONS BY ENTAMOEBA HISTOLYTICA ELICITS ANTI- GAL-LECTIN HEAVY SUBUNIT IGA AND IGG ANTI- BODIES WITH SHARED EPITOPE SPECIFICITY TO THAT OF HUMANS
} By

MOHAMED D. ABD-ALLA ${ }^{1 *}$, ROMAN F. WOLF ${ }^{2}$, GARY L. WHITE ${ }^{2}$, STANLEY D. KOSANKE ${ }^{2}$, DAVID W. CAREY ${ }^{2}$, JACO J. VERWEIJ ${ }^{3}$, YASSER M. M. EL-DESSOUKY ${ }^{1}$, MIE-JIE ZHANG ${ }^{4}$, AND JONATHAN I. RAVDIN ${ }^{1}$

Department of Medicine ${ }^{1}$, Medical College of Wisconsin and Tropical Medicine Department, Faculty of Medicine, Al-Azhar University, Cairo, Egypt, Comparative Medicine ${ }^{2}$, University of Oklahoma Health Sciences Center, Department of Parasitology/Department of Medical Microbiolog ${ }^{3} y$, Leiden University Medical Center, Department of Population Health Biostatistics ${ }^{4}$, Medical College of Wisconsin $\left({ }^{*}\right.$ Correspondence: Abd-Alla, Email: darwish 011012@gmail.com Phone:763-269-6609/+2-0100-747-7212; Fax:+2-022506-3563

\section{Abstract}

Non-human primates, such as baboons (Papio hamadryas anubis), are natural hosts for Entamoeba species; infections can be asymptomatic or result in invasive lethal disease. It was sought to determine whether following natural infection by Entamoeba. histolytica, baboon anti-amebic antibodies recognized native Gallectin, a recombinant portion of the lectin heavy subunit (designated LC3) and specific heavy subunit epitopes; we compared the specificity of anti-amebic antibodies from baboons to that of humans following asymptomatic $E$. histolytica infection or cure of amebic liver abscess (ALA). Female baboons ( $\mathrm{n}=54$ ), aged one to three years of age and living in captivity were screened for infection by real time PCR. E. histolytica infection was found in 37 baboons and was associated with serum anti-LC3 IgG (73\%) and anti-LC3 IgA (46\%) or intestinal anti-Gal-Lectin IgA antibody responses $(49 \%), \mathrm{p}<0.021$ for each compared to that observed with baboons having an E. dispar infection $(\mathrm{n}=10)$ or uninfected baboons $(\mathrm{n}=7)$. The ELISA OD reading for anti-LC3 or anti-lectin antibodies correlated strongly with the presence of a PCR CT value indicative of $E$. histolytica infection. In humans with asymptomatic E. histolytica infection or those recently cured of ALA, $63 \%$ and $57 \%$ had serum anti- LC3 IgA and 65\% and 57\% had serum anti-LC3 IgG antibodies respectively. Epitope- specific synthetic peptides were used as capture antigens in ELISA; for baboons that possessed anti-LC3 and anti-lectin antibodies, $74 \%$ had anti-peptide IgG or IgA antibodies, compared to $86 \%$ of asymptomatic humans and $92 \%$ of ALA subjects $(\mathrm{P}>0.05)$.

Keywords: Entamoeba histolytica; baboons Papio; Gal-lectin; natural infection; mucosal immunity. 


\section{Introduction}

Given the susceptibility of old world primates to $E$. histolytica infection, experimental infection and host immunity should be studied (Jackson et al, 1990; Pang et al, 1993; Verweij et $a l$, 2003a). Mucosal and humoral immune responses and antibody specificity to the E. histolytica Gal-lectin, the function of which is essential for the parasite's colonization of the gut and pathogenesis of disease (Petri et al, 1987, Chadee et al, 1987, Ravdin et al, 1981), has not been defined. The immune response to experimental $E$ histolytica infection has been studied in mice, gerbils, rats, and guinea pigs, (Krupp 1974; Ghadirian and Meerovitch, 1978; 1980; Jain et al, 1980; Martinez et al, 1980; Sepulveda 1980; Perti and Ravdin 1990, Soong et al, 1995; Lotter et al, 2000; Ivory and Chadee 2007; Carrero et al, 2010; Cho et al, 2010; Guo et al, 2008, 2011; Becker et al, 2011). However, natural infection with $E$. histolytica does not occur in these experimental hosts. A high prevalence of $E$. histolytica infection $(41 \%$ \& $44 \%$ respectively) has been reported in captive non-human primates, as detected by PCR (Levecke et al., 2010, 2007). Wild-trapped nonhuman primates have a lower prevalence of E. histolytica (24\%) compared to $(64.4 \%)$ infection with helminthes (Munene et al, 1998).

Infection of humans with $E$. histolytica induces intestinal and serum antiamebic antibodies that recognize native Gal-lectin (Ravdin et al, 1990, Abou Al-Maged et al, 1996) and a recombinant protein (designated LC3) that en- compasses amino acids 758 to 1134 of the lectin`s heavy subunit (Soong et al, 1995). Specific IgG and IgA epitopes of the LC3 protein were determined by patterns of antibody recognition of overlapping recombinant LC3 protein fragments in ELISA, followed by fine mapping using the same strategy with synthetic peptides (Abd-Alla et al, 2004). Intranasal immunization of baboons with epitope-specific synthetic peptides with cholera toxin as adjuvant elicited serum $\operatorname{IgG}$ and intestinal $\operatorname{IgA}$ antibodies that recognized native lectin, purified recombinant LC3 protein and inhibited the in vitro galactosespecific adherence of E. histolytica trophozoites to Chinese hamster ovary cells (Abd-Alla et al, 2007).

The goals of the research reported herein were to determine the prevalence of asymptomatic E. histolytica infection in baboons living in captivity, whether such infections elicited serum and intestinal antibodies to the E. histolytica Gal-Lectin heavy subunit, and if baboons and humans exhibit shared heavy subunit epitope specificity. The outcome of such studies would be of significance in regard to the use of baboons as experimental hosts of E. histolytica for study of host immunity and development of an amebiasis subunit vaccine with high potential for application in humans.

\section{Materials and Methods}

Baboon Population: Baboons (Papio hamadryas anubis) of both genders and various ages were housed as large breeding groups within indoor and outdoor areas. When obtaining samples, baboons were single-housed in alumi- 
num cages at the University of Oklahoma Health Sciences Center's (OUHSC) Comparative Medicine's facility, which is accredited by the Association for Assessment and Accreditation of Laboratory Animal Care International. All procedures were approved by the OUHSC and University of Minnesota Institutional Animal Care and Use Committees. Baboons were fed a commercial monkey chow twice daily and given fruit, popcorn, peanuts, and other treats once a day.

The 54 female baboons, ages one to three years, utilized in this study were not previously included in other research projects and didn't exhibit any physical or behavioral abnormalities before enrollment. All of the baboons were living under the same conditions and managed by the same personnel. To obtain blood samples, baboons were sedated with Ketamine hydrochloride (approximately $10 \mathrm{mg} / \mathrm{kg} / \mathrm{IM}$ ) and 10 $\mathrm{ml}$ was collected by venipuncture, placed into a serum separator tube on ice. After clotting for 2 hours, the samples were centrifuged for 20 minutes at high speed. Sera were stored at $-80^{\circ} \mathrm{C}$ and shipped on dry ice to the Ravdin laboratory. Stools were collected from each animal separately by placing a clean pad under each cage; fecal samples were aliquoted into a $5 \mathrm{ml}$ tube, frozen in -80 freezers and also sent on dry ice to the Ravdin laboratory.

Human Infection by E. histolytica: Subjects were randomly selected from a prospective longitudinal controlled field study performed in Durban, South Africa (Ravdin et al, 2003, Abd-Alla et $a l, 2006)$ that included a total of 954 controls and 100 index cases(recently cured of amebic liver abscess)(ALA) who were followed every three months for three years. Subjects for this study were randomly selected from the control group $(\mathrm{n}=40)$ when they had a documented asymptomatic E. histolyti$c a$ infection, as determined by fecal culture and zymodeme (Ravdin et al, 2003) and from the index case cohort $(n=35)$ immediately after being cured of amebic liver abscess. Sera from both groups were evaluated by ELISA for anti-LC3 and anti-peptide IgA and IgG antibodies as described below. Studies were performed concurrently with baboon serum ELISA.

Detection of E. histolytica and E. dispar infection of baboons by real time PCR: DNA was extracted from stool samples and stored at $-20 \mathrm{C}$. The QIAamp DNA Stool Mini Kit (Qiagen, Haldin, Germany) was used to extract DNA from feces according to the manufacture's protocol (Abd-Alla et al, 2007). PCR primers and detection probes were used based on the known episomal repeat sequences for E. histolytica (Garfinkel et al, 1989); successful amplification and detection of DNA specific to E. histolytica and $E$. dispar has been previously verified (Verweij et al, 2003a). For the amplification and detection of the internal control, we used PCR primers and a detection probe specific for PhHV-1 (Niesters, 2002). The E. histolyticaspecific primers and probe set consisted of forward primer histolytica-50F (5'-CATTAAAAATGGTGAGGTTCT T AGGAA-3'), reverse primer histolyti-ca-132R (5'-TGGTCGTCGTCTA 
GGCAAAATATT-3') and E. histolyti$c a$-specific double-labeled probe-TEX 615'5TTGACCAATTTACACCGTTG ATTTT TCG GA -3' Iowa Black RQ. The specific primers of $E$. dispar were forward primer dispar ('5-GGATCCT CCAAAAAATAAAGTTTTATCA-3') reverse primer dispar ('5-ATCCACAG AACGATATTGGATACCTAGTA-3') and $E$. dispar specific double labeled probe (JOE NHS Ester ' 5 -TCTCTGCT ACAACCTC-3' Iowa Black FQ) [Integrated DNA Technology (IDT), Coralville, IA 52241. 1-800-3282661]. PhHV-1- specific primers and probe set consisted of forward primer PhHV267s (5'-GGGCGAATCACAGATTG AATC-3'), reverse primer PhHV-337 as (5'-GCGGTTCCAAACGTACCAA $\left.-3^{\prime}\right)$ and specific double-labeled probe PhHV-CY5-'5-TTTTTATGTGTCCG GCCACCATCTGGATC-3'Black Hole Quencher 2 (IDT, USA).

The amplification reactions were performed in a volume of $20 \mathrm{ul}$ for each reaction. For 32 reactions (samples) 128ul PCR buffer mix (TaqMan master: Roch, Cat. No.04 735536 001), with 16 ul $1 \%$ BSA, 313.6ul $\mathrm{H}_{2} \mathrm{O}+40$ pmol (4ul) E. histolytica primer, 40 pmol (4ul) PhHV-1primer+80pmol (3.2ul) E. histolytica specific doublelabeled probe+32pmol (3.2ul) PhHV-1specific double-labeled probe and $5 u l$ of DNA sample. Thermo-cycling amplification conditions consisted of 15 min at $95^{\circ} \mathrm{C}$ followed by 50 cycles of 15 seconds at $95^{\circ} \mathrm{C}, 30$ seconds at $60 \mathrm{C}^{\circ}$ and 30 seconds at $72 \mathrm{C}^{\circ}$, performed by the Roche 2.0 version 4.0 LightCycler PCR Machine (Roche).
ELISA for detection of baboon and human anti-lectin, anti- LC3 and antipeptide antibodies: ELISA was performed as described previously (Ravdin et al, 1990; Abd-Alla et al, 2004): purified recombinant $52 \mathrm{kDa}$ LC3 protein (Song et al., 1995), purified native Gal-lectin (Petri et al, 1987), or synthetic peptides specific for each of the four putatively protective Gal-lectin heavy subunit IgA epitopes (Abd-Alla et al, 2004) were utilized to coat, 96well microtiter flat-bottomed polystyrene ELISA plates, non-reactive sites were blocked with $1 \%$ BSA. The serum was studied at a 1:100 dilution for antibody detection in PBS-Tween (1\% BSA); alkaline phosphatase-conjugated goat anti-human IgG (SIGMA, St. Louis, MO) or anti-human IgA antibodies (ICN Biomedicals (Costa Mesa, California) were diluted at 1:5000 to detect IgG and 1:2500 to detect IgA in PBSTween 1\% BSA at $100 u l$ well and incubated for 2 hours at room temperature. Plate reading and correction for nonspecific background binding were performed as described (Ravdin et al, 1990).

For detection of antigen-specific intestinal $\operatorname{IgA}$ antibodies, purified native Gal-lectin protein (Petri et al, 1987) or a combination of four synthetic peptides were utilized in ELISA (Abo-ElMaged et al, 1996; Abd-Alla et al, 2004, 2007). Briefly, the flat-bottomed microtiter ELISA plates were coated with lectin protein $(0.1 \mathrm{ug} / \mathrm{well})$ or synthetic peptides (1ug each peptide per well) and non-reactive sites were blocked with $1 \%$ BSA. Fecal samples were mixed with an equal volume of 
PBS containing $2 \mathrm{mM}$ PMSF and 100 $u l$ / well were incubated for 2 hours at room temperature or overnight at $4^{\circ} \mathrm{C}$. Alkaline phosphatase-conjugated goat anti-human IgA antibodies (SIGMA, St. Louis, MO.) were added (1:3000) in PBS-Tween containing 1\% BSA for 2 hours incubation at room temperature. Plate reading with correction for nonspecific background binding was performed (Ravdin et al, 1990).

Statistical analysis: Results were expressed as the mean, $(+3 \mathrm{SD})$ of percent positive and percent negative. The $\mathrm{Z}$ test (converted to $\mathrm{P}$ value) and unpaired student t-test was used to determine the significance of difference (Sox, 1986). In the current study two sample $\mathrm{z}$ tests were used for percentages. The null hypothesis says that the percentages of positive test in the two groups are the same (difference in percentages $=0.0 \%$ ). The alternative says that percentages of positive test in the two groups are different. Using type one error (alpha) equal 0.05:- $Z>$ $1.645=$ significant changes and $-\mathrm{Z}<$ $1.645=$ insignificant changes.

\section{Results}

The prevalence of $E$. histolytica and $E$. dispar infection in the baboon population was determined by real time PCR. Of the 54 baboons studied, 37 (68.5\%) were infected with $E$. histolytica, $10(18.5 \%)$ with $E$. dispar and only $7(13.0 \%)$ were uninfected; mixed infections were not observed. Baboons were more likely to be infected with $E$. histolytica than $E$. dispar $(\mathrm{P}<0.01)$ or to be uninfected $(\mathrm{P}<0.01)$. Of the baboons infected with an $E$. histolytica, $84 \%$ exhibited either a serum or intestinal anti-lectin antibody response, compared to only $20 \%$ of E. dispar infected baboons $(p<0.001)$. None of the uninfected baboons exhibited a serum or intestinal anti-lectin antibody response. In E. histolytica infected baboons; $49 \%, 46 \%$, \& $73 \%$ respectively had positive ELISAs for intestinal antilectin IgA, serum anti-LC3 IgA and serum anti-LC3 IgG antibodies, with the latter being a statistically significant higher percentage $(\mathrm{P}<0.01$, Tab. 1).

Table 1: Prevalence of baboon anti-amebic antibodies found after asymptomatic infection in captivity with $E$. histolytica $(\mathrm{n}=37)$.

infection in captivity with E. histolytica $(\mathrm{n}=37)$.
\begin{tabular}{|l|l|l|}
\hline Antibody Tested & ELISA $(+)$ & ELISA(-) \\
\hline Intestinal Anti-lectin IgA & $18(49 \%)$ & $19(51 \%)$ \\
\hline Serum Anti-LC3 IgA & $17(46 \%)$ & $20(54 \%$ \\
\hline Serum Anti-LC3 IgG & $27(73 \%)$ & $10(27 \%)$ \\
\hline
\end{tabular}
* P $<0.01$ compared to prevalence of intestinal anti-lectin IgA or serum anti-LC3 IgA antibodies.

Figs. 1A thorough 1C illustrate relationship between ELISA OD value for each anti-amebic antibody studied and PCR CT value for all 54 baboons studied. There is a strong correlation between having a positive PCR for E. histolytica DNA and a positive ELISA OD value for anti-amebic antibodies (Figs. $1 \mathrm{~A}-1 \mathrm{C}, \mathrm{P}<0.01$ ). Greater ELISA OD values were observed in antibody-positive E. histolytica infected baboons, compared to antibody-positive $E$. dispar infected subjects (Fig. 1A-C, $\mathrm{P}<0.01$ ). Baboons having a negative PCR CT value $(>35)$ all demonstrated a negative ELISA for any of anti-lectin or anti-LC3 antibodies studied (Figures 1A-1C). 

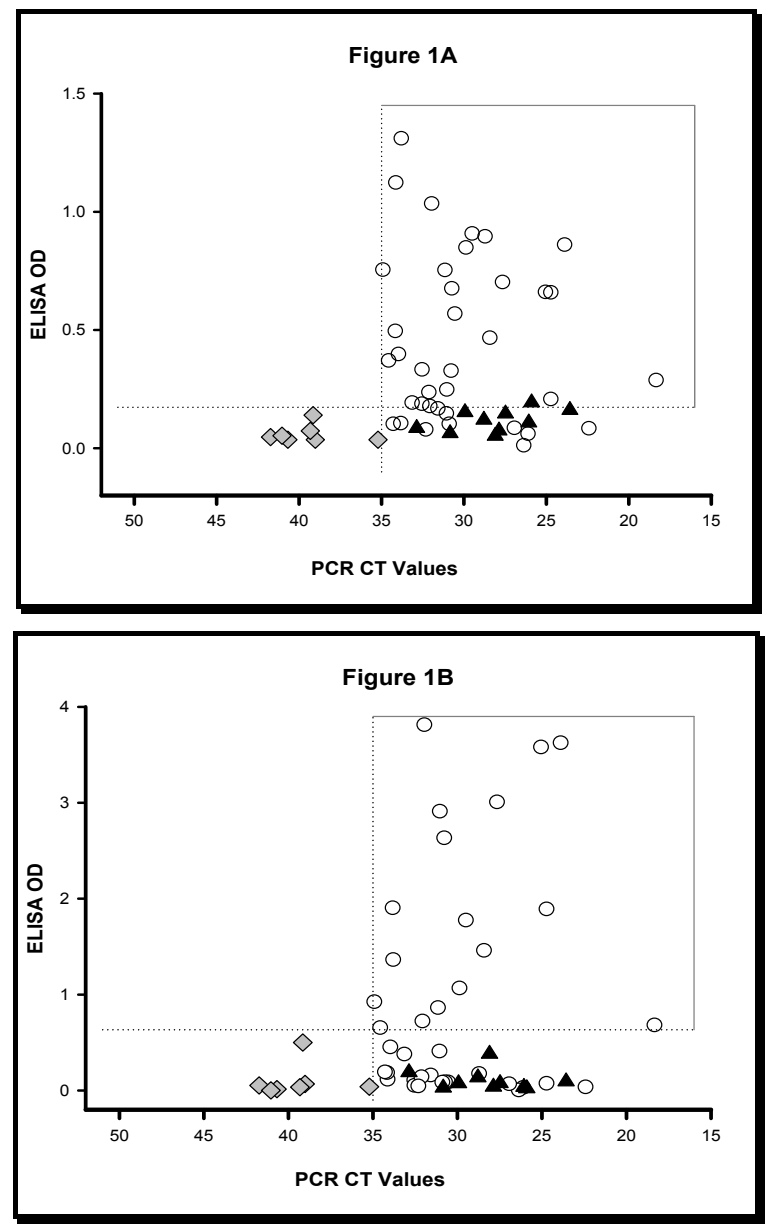

Figure 1C

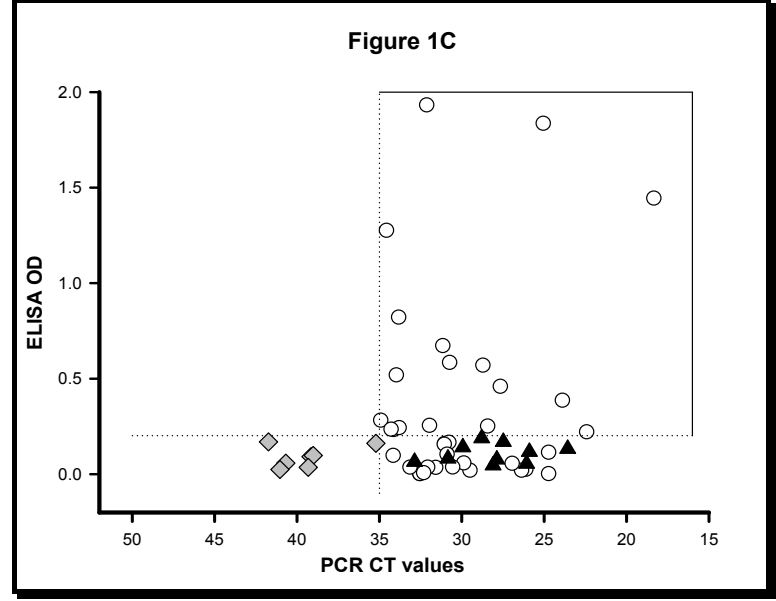




\section{Figure Legend}

Fig1: Correlation between ELISA OD values for assay of baboon sera for anti-LC3 IgG antibodies (1A), anti-LC3 IgA antibodies (1B) and for assay of baboon feces for intestinal anti-lectin IgA antibodies (1C) and fecal PCR CT values. A PCR CT value of 35 or less indicates a positive assay for detection of $E$. histolytica or $E$. dispar DNA in feces. All of the baboons with a negative PCR CT value $(\diamond)$ also had negative ELISAs (OD value below cutoff) for all three of the antibodies studied (1A-1C). There was a positive association with a PCR indicative of a $E$. histolytica infection (O) with the presence of serum anti-LC3 IgG, serum anti-LC3 IgA and intestinal anti-lectin IgA antibodies $(\mathrm{P}<0.01$ for each, $1 \mathrm{~A}-1 \mathrm{C})$, but not so for PCRs indicative of $E$. dispar infection $(\mathbf{\Delta}), 1 \mathrm{~A}-1 \mathrm{C})$.

For comparison, among 40 human subjects with asymptomatic $E$. histolytica infection, $63 \%$ had ELISAs positive for serum anti-LC3 IgA antibodies and $65 \%$ for serum anti-LC3 $\operatorname{IgG}$ antibodies; comparable results were observed for the 35 human subjects recently cured of amebic liver abscess (Tab. 2).

Table 2: Prevalence of human anti-amebic antibodies found in Durban, South Africa following asymptomatic E. histolytica infection or after cure of amebic liver abscess.

\begin{tabular}{|l|l|l|}
\hline Antibody Tested & $\begin{array}{l}\text { Asymptomatic Controls } \\
(\mathrm{n}=40) \text { ELISA+ }\end{array}$ & $\begin{array}{l}\text { Amebic Liver Abscess } \\
(\mathrm{n}=35) \text { ELISA+ }\end{array}$ \\
\hline Intestinal Anti-lectin IgA & N.A. & N.A. \\
\hline Serum Anti-LC3 IgA & $25(63 \%)$ & $20(57 \%)$ \\
\hline Serum Anti-LC3 IgG & $26(65 \%)$ & $20(57 \%)$ \\
\hline
\end{tabular}

Among the baboons that were infected with E. histolytica and antibodypositive, it was determined whether they possessed antibodies to a combination of the four Gal-lectin heavy subunit IgA epitope-specific synthetic peptides (Abd-Alla et al, 2004, 2006). The baboons with intestinal anti-lectin $\operatorname{IgA}$, serum anti-LC3 $\operatorname{IgA}$ and serum anti-LC3 IgG: $83 \%, 41 \%$ \& $70 \%$ respectively also had positive ELISAs for the peptide epitopes (Tab. 3).

Table 3: Percentage of asymptomatically baboons infected with E. histolytica, positive for one of anti-amebic antibodies studied, and recognized the Gal-lectin heavy subunit epitope-specific synthetic peptides on ELISA

\begin{tabular}{|l|l|}
\hline Infected Baboons positive for antibody indicated below & $(+)$ Synthetic peptide ELISA \\
\hline Intestinal Anti-lectin IgA antibodies & $15 / 18(83 \%)$ \\
\hline Serum Anti-LC3 IgA antibodies & $7 / 17(41 \%)$ \\
\hline Serum Anti-LC3 IgG antibodies & $19 / 27(70 \%)$ \\
\hline For any one of the 3 antibodies above & $23 / 31(74 \%)$ \\
\hline
\end{tabular}

Control studies were performed utilizing the serum anti-LC3 IgA and IgG antibody positive samples from human subjects with asymptomatic infection; $88 \%$ and $54 \%$ respectively had positive anti-peptide ELISA results. Among the antibody positive human subjects cured of amebic liver abscess, $90 \%$ and $80 \%$ of subjects respectively exhibited a positive ELISA for anti-peptide IgA or IgG antibodies. In asymptomatically infected baboons and humans who were also either anti-lectin or anti-LC3 antibody positive, $74 \%$ and $86 \%$ respectively exhibited a positive antipeptide ELISA (Tabs. 3 \& 4) indicat- 
ing that baboons share recognition with humans for the same four Gal-lectin heavy subunit epitopes. Although the antibody positive- amebic liver abscess subjects appeared to have a higher per- centage of positive anti-peptide ELISA ( $91 \%, \mathrm{P}=0.275$ compared to asymptomatically infected humans), this was not a statistically significant difference (Tab. 4).

Table 4: Percentage of asymptomatic humans with E. histolytica infection or cured of amebic liver abscess, positive for one of anti-amebic antibodies studied and also recognized Gal-lectin heavy subunit epitope-specific synthetic peptides on ELISA

\begin{tabular}{|l|l|l|}
\hline $\begin{array}{l}\text { Humans positive for antibody } \\
\text { indicated below }\end{array}$ & $\begin{array}{l}\text { Asymptomatic Controls, (+) } \\
\text { Synthetic peptide ELISA }\end{array}$ & $\begin{array}{l}\text { Amebic liver abscess subjects, } \\
(+) \text { Synthetic peptide ELISA }\end{array}$ \\
\hline Serum Anti-LC3 IgA & $22 / 25(88 \%)$ & $18 / 20(90 \%)$ \\
\hline Serum Anti-LC3 IgG & $14 / 26(54 \%)$ & $16 / 20(80 \%)$ \\
\hline For any of two antibodies above & $24 / 28(86 \%)$ & $21 / 23(91 \%)$ \\
\hline
\end{tabular}

\section{Discussion}

In captivity baboons are ground dwellers (Beaver et al, 1988; Munene et al, 1998); those included in the current study were housed at OUHSC in large groups, were in full contact with one another and ate fresh fruits and vegetables. The animal caretakers have been the source of outbreaks of amebic infection in non-human primates (Miller et al, 1990; Hamlen and Lawrence, 1994); however, we did not investigate that possibility in this study. E. histolytica infection has been found to be more frequent than E. dispar infection in captivity (Levecke et al, 2010), as observed in this study. The findings of a strong correlation between the results for PCR for detection of E. histolytica DNA and for ELISA to detect serum and intestinal anti-amebic antibodies further supports the accuracy of PCR using species specific primers and real time PCR (Verweij et al, 2003b) for diagnosis and differentiation of E. histolytica from $E$. dispar infection in baboons. Entamoeba species exhibit variability in pathogenicity among nonhuman primate hosts; captive Drills
(Mandrillus leucophacaeus) and Barbary (Macaca sylvanus) macaques were found to be asymptomatic carriers of $E$. nuttalli, yet fatal disease resulted when the parasite was transmitted to captive Colobus guereza and Hanuman llangurs monkeys (Schauerte et al, 2010). In addition, to E. histolytica (Pang et al, 1993; Verweij et al, 2003a), other gastrointestinal protozoan are commonly found in non-human primates, including Giardia spp. (Peisert et al, 1983; Hamlen and Lawrence, 1994; Kalishman et al, 1996), Cryptosporidium spp. (Go'mez et al, 1992; Kalishman et al, 1996; da Silva et al, 2003) and Balantidium coli (Nakauchi, 1999). The clinical presentation of protozoan parasitic infection in the nonhuman primates varies from loose stools, watery diarrhea and hemorrhagic dysentery to extra-intestinal invasion (liver abscesses), and even death. Outbreaks and deaths caused by E. histolytica are frequently reported in nonhuman primates (Loomis et al, 1983; Beaver et al, 1988; Marquez-Monter et al, 1991; Verweij et al, 2003a). Lastly, non-human primates may harbor many 
of the same gastrointestinal pathogens as found in humans (Peisert et al., 1983; Hamlen and Lawrence, 1994; Kalishman et al, 1996; Go'mez et al, 1992; da Silva et al, 2003; Nakauchi, 1999) and thus, can be a source for zoonotic infections (Pang et al, 1993; Verweij et al, 2003a).

Following asymptomatic E. histolyti$c a$ infection, approximately $50 \%$ of the infected baboons developed intestinal anti-lectin IgA antibodies and anti-LC3 serum IgA antibodies; over $70 \%$ developed serum anti-LC3 IgG antibodies. As this was a point prevalence study, we have no information regarding the duration of $E$. histolytica infection in the baboons. Previously, in human field studies we demonstrated that intestinal anti-lectin IgA antibodies were a more sensitive indicator than a single fecal PCR study of the recent asymptomatic $E$. histolytica infection (Abd-Alla et al, 2006). These baboons may have been infected for longer than three to six months, as the prevalence of intestinal anti-lectin IgA antibodies was lower than the serum IgG antibody response, which can be sustained for years (Abd-Alla et al, 2006). The point prevalence of serum anti-LC3 IgG and IgA antibodies in a cohort of asymptomatically infected humans and those recently cured of amebic liver abscess were nearly identical to that observed in the baboons. As the immunoglobulin subclasses in baboons, compared to other monkey`s, are most analogous to those of humans (Shearer et al, 1999), it is not surprising to observe similar patterns of mucosal and humoral immune responses to E. histolytica infec- tions. As expected, E. dispar infection did not elicit humoral or mucosal antiamebic antibody responses in the baboons; a finding concordant with human clinical studies (Jackson et al, 1985; Abou El-Maged et al, 1996; Ravdin et al, 1990, 2003; Abd-Alla et al, 2000; Haque et al, 2001).

When evaluating the recognition of the four heavy subunit epitope-specific synthetic peptides by baboon and human anti-amebic antibodies, the percent positive ELISAs for anti-peptide antibodies were comparable in asymptomatically infected baboons and humans, indicating that $E$, histolytica infection of baboons elicited antibodies with shared Gal-lectin heavy subunit epitope specificity. These findings correlate with studies of experimental intranasal immunization of baboons with these same epitope-specific synthetic peptides, which elicited intestinal IgA and humoral $\operatorname{IgA}$ and $\operatorname{IgG}$ antibodies that recognized the native Gal-lectin, bound to the surface of viable E. histolytica trophozoites and inhibited the in vitro galactose-sepecific adherence of trophozoites to Chinese hamster ovary cells (Abd-Alla et al, 2007).

Of interest, the seropositive subjects recently cured of amebic liver abscess had a higher percent of positive ELISA for the peptide epitopes and a higher OD value for anti-LC3 antibodies. Previously, the present authors demonstrated that over 36 months of follow up, ELISA OD values for anti-amebic antibodies are higher in liver abscess cohort, compared to antibody positive controls (Abd-Alla et al, 2006). 


\section{Conclusion}

Asymptomatic E. histolytica and E. dispar infections occur in baboons while in captivity. Asymptomatic $E$. histolytica infection of baboons elicits anti-amebic anti-bodies with prevalence analogous to that observed during asymptomatic infection in humans. Baboon and human antibodies recognize native Gal-lectin, a Gal-lectin heavy subunit-based recombinant protein (LC3) and Gal-lectin heavy subunit based epitope-specific synthetic peptides. Given that other experimental animal models of $E$. histolytica infection utilize hosts that aren't subject to natural infection by the parasite and have immune systems that may not produce the analogous epitope-specific antibody responses, baboons may be a more appropriate experimental animal host for the study of immune response to E. histolytica infection and to determine the efficacy of the experimental amebiasis subunit vaccines. The baboons naturally infected with $E$. histolyti$c a$ while in captivity develop serum and intestinal anti-Gal lectin antibody responses that were found to recognize the same four Gal-lectin heavy subunit epitopes as antibodies from humans who were asymptomatically infected or recently cured of ALA. Thus, the baboons constitute an ideal experimental host for study of E. histolytica infection, mucosal immunoresponses and the efficacy of an amebiasis subunit vaccine.

\section{References}

Abd-Alla, MD, Wahib, AA, Ravdin, JI, 2000: Comparison of antigen capture ELISA to stool culture in methods for detection of asymptomatic Entamoeba species infection in Kafer-Daoud, Egypt. Amer. J. Trop. Med. Hyg. 62, 5:579-82.

Abd-Alla, MD, Jackson, TGFH, Soong, G, Mazinac, M, Ravdin, JI, 2004: Identification of Entamoeba histolytica galactose inhabitable lectin epitopes recognized by human IgA antibodies following cure of amebic liver abscess. Infect. Immun. 72:3974-80.

Abd-Alla, MD, Jackson, TGFH, Rogers, T, Reddy, S, Ravdin, JI, 2006: Mucosal immunity to asymptomatic Entamoeba histolytica and Entamoeba dispar infection is associated with peak intestinal anti-Lectin Immunoglobulin A Antibody Response. Infect. Immun. 74:3897-903.

Abd-Alla, MD, White, GL, Rogers, T B, Cary, ME, Cary, DW, et al, 2007: Adherence inhibitory IgA antibody response in baboons elicited by use of synthetic intranasal lectin-based amebiasis subunit vaccine. Infect. Immun. 75:3812-22.

Abou-E1-Magd, I, Soong, CJ, El-Hawey, AM, Ravdin, JI, 1996: Humoral and mucosal IgA antibody response to a recombinant $52-\mathrm{kDa}$ cysteine-rich portion of the Entamoeba histolytica galactose-inhibitable lectin correlates with detection of native $170-\mathrm{kDa}$ lectin antigen in serum of patients with amebic colitis. J. Infect. Dis. 174:157-62

Beaver, PC, Blanchard, JL, Seibold, HR, 1988: Invasive amebiasis in naturally infected New-World and OldWorld monkeys with and without clinical disease. Am. J. Trop. Med. Hyg. 39:343-52. 
Becker, S, Hoffman, P, Houpt, ER, 2011: Efficacy of anti-amebic drugs in a mouse model. Am. J. Trop. Med. Hyg. 84:581-6

Carrero, JC, Contreras-Rojas, A, Sánchez-Hernández, B, Petrosyan, P, Bobes, RJ, et al, 2010: Protection against murine intestinal amoebiasis induced by oral immunization with the $29 \mathrm{kDa}$ antigen of Entamoeba histolytica and cholera toxin. Exp. Parasitol. 126:359-65.

Chadee, K, Petri, WA, Innes, DJ, Ravdin, JI, 1987: Rat and human colonic mucins bind to and inhibit the adherence lectin of Entamoeba histolytica. J. Clin. Invest. 80:1245-54.

Cho, KN, Becker, SM, Houpt, ER, 2010: The NF-KappaB p50 subunit is protective during intestinal Entamoeba histolytica infection of 129 \& C57BL/6 mice. Infect. Immun. 78:1475-81.

Da Silva, AJ, Caccio, S, Williams, C, Won, KY, Nace, EK, et al, 2003: Molecular and morphologic characterization of a Cryptospordium genotype identified in lemurs. Vet. Parasitol. 111: 297-307.

Garfinkel, LI, Giladi, M, Huber, M, Gitler, C, Mirelman, D, et al, 1989: DNA probes specific for Entamoeba histolytica possessing pathogenic and nonpathogenic zymodemes. Infect. Immun. 57:926-31.

Ghadirian, E, Meerovitch, E, 1978: Vaccination against hepatic amebiasis in hamsters. J. Parasitol. 64:742-3.

Ghadirian, E, Meerovitch, E, Hartmann, DP, 1980: Protection against amebic liver abscess in hamsters by means of immunization with amebic antigen and some of its fractions. Am. J. Trop. Med. Hyg. 29:779-84.

Go'mez, MS, Gracenea, M, Gosalbez, P, Feliu, C, Ensenat, C, et al, 1992: Detection of oocysts of Cryptosporidium in several species of monkeys and in one prosimian species at the $\mathrm{Ba}$ rcelona Zoo. Parasitol. Res. 78:619-20.

Guo, X, Roberts, MR, Becker, SM, Podd, B, Zhang, Y, et al, 2011: Leptin signaling in intestinal epithelium mediates resistance to enteric infection by Entamoeba histolytica. Mucosal Immunol. 4:294-303.

Guo, X, Stroup, SE, Houpt, ER, 2008: Persistence of Entamoeba histolytica infection in CBA mice owes to intestinal IL-4 production and inhibition of protective IFN-gamma. Mucosal Immunol. 1:139-46.

Hamlen, HJ, Lawrence, JM, 1994: Giardiasis in laboratory-housed squirrel monkeys: A retrospective study. Lab. Anim. Sci. 44:235-9.

Haque, R, Ali, IM, Sack, RB, Farr, BM, Ramakrishnan, G, et al, 2001: Amebiasis and mucosal IgA antibody against Entamoeba histolytica adherence lectin in Bangladeshis Children. J. Infect. Dis. 183:1787-93.

Ivory, CP, Chadee, K, 2007: Intranasal immunization with Gal-inhibitable lectin plus an adjuvant of $\mathrm{CpG}$ oligodeoxynucleotides protects against Entamoeba histolytica challenge. Infect. Immun. 75:4917-22.

Jackson, TFHG, Gatheram, V, Simijee, AE, 1985: Seroepidemiolgic study of antibody response to the zymodeme of Entameba histolytica. Lancet, 1:7168 . 
Jackson, TFHG, Sergeant, PG, Visser, PS, Gathiram, V, Suparsad, S, et al, 1990: Entamoeba histolytica: naturally occur infections in baboons. Arch. Invest. Med. (Mex) 21, 1:153-6

Jain, P, Sawney, S, Vinayak, VK, 1980: Experimental amoebic infection in Guinea pigs immunized with low grade amoebic infection. Trans. R. Soc. Trop. Med. Hyg. 74:347-55.

Kalishman, J, Paul-Murphy, J, Scheffer, J, Thomson, JA, 1996: Survey of Cryptosporidium and Giardia spp. in a captive population of common marmosets. Lab. Anim. Sci. 46:116-9.

Krupp, IM, 1974: Protective immunity to amebic infection demonstrated in guinea pigs. Am. J. Trop. Med. Hyg. 23:355-62.

Levecke, B, Dorny, P, Geurden, T, Vercmmen, F, Vercruysse, J, 2007: Gastrointestinal protozoa in nonhuman primates of four zoological gardens in Belgium. Vet. Parasitol. 148:236-46

Levecke, B, Dreesen, L, Dorny, P, Verweij, J, Vercammen, F, et al, 2010: Molecular identification of Entamoeba spp. in captive none human primates. J. Clin. Microbiol. 48:2988-90

Loomis, MR, Britt, JO, Gendron, A P, Holshuh, HJ, Howard, EB, 1983: Hepatic and gastric amebiasis in black and white colobus monkeys. J. Am. Vet. Med. Assoc. 183:1188-91.

Lotter, H, Khajawa, F, Stanley, SL, Jr, Tannich, E, 2000: Protection of gerbils from amebic liver abscess by vaccination with a 25 -mer peptide derived from the cysteine-rich region of Entamoeba histolytica galactose-speci- fic adherence lectin. Infect. Immun. 68: 4416-21.

Marquez-Monter, H, Fuentes-Orozco, R, Correa-Lemus, I, Becker, I, 1991: Invasive amebiasis in a spider monkey (Ateles geoffroyi): Case report and a short review of the literature of amebiasis in nonhuman primates. Arch. Invest. Med. 22:75-8.

Martinez Reyes, R, Gonzalez-Pacheco, I, Gomez-Reyes, I, de la Torre, M, Sepulveda, B, 1980: Inuccion de inmunidad antimiabisica en primates subhumanos. Con antigeno lisosoma de Entamoeba histolytica. VI. Inoculacion intrahepatica de $E$. histolytica viulenta en monos. Arch. Invest. Med. Mexico 11:267-73.

Miller, RA, Brondson, MA, Kuller, L, Morton, WR, 1990: Clinical and parasitologic aspects of crytosporidiosis in non-human primates. Lab. Anim. Sci. 40:42-6.

Munene, E, Otsyula, M, Mbaabu, D NA, Mutahi, WT, Muriuki, SMK, et $\boldsymbol{a l}$, 1998: Helminth and protozoan gastrointestinal tract parasites in captive and wild-trapped African non-human primates. Vet. Parasitol. 78:195-201.

Nakauchi, K, 1999: The prevalence of Balantidium coli infection in fifty-six mammalian species. J. Vet. Med. Sci. 61:63-5.

Niesters, HG, 2002: Clinical virology in real time. J. Clin. Virol. 25, 3:S3-12.

Pang, VF, Chang, CC, Chang, WF, 1993: Concurrent gastric and hepatic amebiasis in a dusky leaf monkey (Presbytis obscurus). J. Zoo Wildl. Med. 24:204-7. 
Peisert, W, Taborski, A, Pawlowski, Z, Karlewiczowa, R, Zdun, M, 1983: Giardia infection in animal Poznan' Zoo. Vet. Parasitol. 13:183-6.

Petri, WA, Jr, Smith, R, Schlesinger, P, Ravdin, JI, 1987: Isolation of galactose-binding lectin which mediates in vitro adherence of Entamoeba histolytica. J. Clin. Investig. 80:1238-144.

Ravdin, JI, Guerrant, RL, 1981: The role of adherence in cytopathogenic mechanisms of Entamoeba histolytica: Study with mammalian tissue culture cells and human erythrocytes. J. Clin. Invest. 68:1305-13.

Ravdin, JI, Abd-Alla, MD, Welles, SL, Reddy, S, Jackson, TGFH, 2003: Intestinal anti-lectin immunoglobulin A antibody response and immunity to Entamoeba dispar infection following cure of amebic liver abscess. Infect. Immun. 7:6899-905.

Ravdin, J, Jackson, TFHG, Petri, W A, Murphy, C, Ungar, B, et al, 1990: Association of serum antibodies to adherence lectin with invasive amebiasis and asymptomatic infection with Entamoeba histolytica. J. Infect. Dis. 162: 768-72.

Schauerte, N, Hensel, C, Thien, HV, Tannich, E, 2010: Lethal Entamoeba natalli outbreak in captive monkeys of two German Zoos (2010): Montréal amebiasis 2010 workshop molecular approach and clinical aspects, September $22-24^{\text {th }}$. Institute International de Parodontie.
Shearer, MH, Dark, RD, Chodosh, J, Kennedy, RC, 1999: Comparison and characterization of immunoglobulin $G$ subclasses among primate species. Clin. Diag. Lab. Immunol. 6:953-8.

Sepulveda, B, 1980: Induccion de immunidad protector antiamibiasica en primate's subhumanos con antigeno lisosomal de Entamoeba histolytica. Comentarios y conclusiones. Arch. Invest. Med. Mexico 11:275-86.

Soong, CJG, Kain, KC, Abd-Alla, M D, Jackson, TFHG, Ravdin, JI, 1995: A recombinant cysteine-rich section of the Entamoeba histolytica galactose-inhibitable lectin is efficacious as a subunit vaccine in the gerbil model of amebic liver abscess. J. Infect. Dis. 171: 645-51.

Sox, HC, Jr. 1986: Probability theory in the use of diagnostic test. Ann. Int. Med. 104:60-6.

Verweij, JJ, Laeijendecker, D, Brien en, EAT, Van Lieshout, L, Van Polde rman, AM, 2003a: Detection and identification of Entamoeba species by reverse line hybridisation in stool samples. J. Clin. Microbiol. 41:5141-5.

Verweij, JJ, Vermeer, J, Brienen, E A, Blotkamp, C, Laeijendecker, D, et al, 2003b: Entamoeba histolytica infections in captive primates. Parasit. Res. 90:100. 